\title{
Natural radioactivity concentration in raw materials used for manufacturing refractory products
}

\author{
A.A. Fathivand ${ }^{1}$ and J. Amidi ${ }^{2}$ \\ ${ }^{1}$ Nuclear Science and Technology Research Institute, PO Box, 11365-3486 Tehran, Iran \\ ${ }^{2}$ National Radiation Protection Department, PO Box, 14155-4494 Tehran, Iran
}

\begin{abstract}
The natural radioactivity due to presence of ${ }^{238} \mathrm{U},{ }^{232} \mathrm{Th}$ and ${ }^{40} \mathrm{~K}$ in zirconium minerals used in the Iranian ceramic industry, tiles and waste sludges has been measured. The measurements were made by gamma spectrometry system with a high pure germanium (HPGe) detector connected to multichannel analyzer (MCA). The average concentrations of ${ }^{238} \mathrm{U}$ and ${ }^{232} \mathrm{Th}$ determined in the mineral samples $\left(3000,500 \mathrm{~Bq} \mathrm{~kg}^{-1}\right.$ respectively) are much higher than concentrations found in the earth's crust. The specific activity of ${ }^{238} \mathrm{U}$ and ${ }^{232} \mathrm{Th}$ in tiles $\left(62,54 \mathrm{~Bq} \mathrm{~kg}^{-1}\right.$ respectively) are not higher than in other building materials.

The ${ }^{238} \mathrm{U}$ concentration of sludges $\left(150 \mathrm{~Bq} \mathrm{~kg}^{-1}\right)$ is higher than the mean value for the earth's crust. The results are examined on the basis of the existing national limit.
\end{abstract}

\section{INTRODUCTION}

Many materials that are usually found in the earth's crust contain small but measurable amount of naturally occurring radioactivity (NORM). Some particular ores contain natural radionuclides at levels much higher those usually present in earth's crust, and are also subject to radioisotope enrichment, during technological process, known as technologically enhanced natural radioactivity (TENORM). The term TENORM was proposed to distinguish the NORM from that enhanced by technological process. Typical concentrations of ${ }^{238} \mathrm{U}$ and ${ }^{232} \mathrm{Th}$ in the earth's crust and in various natural materials are compared in Table 1.

The investigations of zirconium ores as sources of TENORM began in the late 1970 and early $1980[1,2]$. These works highlighted the relatively high concentrations of natural radionuclides in zircon ores. Zirconium silicate $\left(\mathrm{ZrSiO}_{4}\right)$ is the most important compounds obtained from zircon sand; baddeleyite is a natural form of zirconium $\left(\mathrm{ZrO}_{2}\right)$. The most important uses of zircon sands are as refractories, foundry sands and ceramic opacifiers. At present, South Africa, Ukraine, India, Brazil and china are the largest exporters of zirconium materials [3].

In Iran, zirconium minerals are widely used in ceramic industry. This sector absorbed about 700 tons (1999-2001) of zircon, principally for opacifier. Iran imports zirconium sands from South Africa, Italy, Ukraine, and to lesser extent, from Germany and Belgium. Radiation dose limits for exposure of Iranian workers is $100 \mathrm{mSv}$ in a period of 5 consecutive years, with a maximum dose of $20 \mathrm{mSv}$ in one year. For the population, the dose limit is $1 \mathrm{mSv} \mathrm{y}^{-1}$ [4].

The internal exposure, through inhalation, and external exposure are the main radiological concern about zirconium use. Gamma radiation dose rate close to bulk quantities of zirconium sands are $1-2 \mu \mathrm{Sv} \mathrm{h}^{-1}$ and simple precautions are generally sufficient to minimize the external radiation exposure. Proper industrial hygiene rules sufficient to avoid internal contamination resulting from zircon powders.

Threshold levels indicated in the Euratom 1996 legislation stipulate minimum activity concentration and total quantity of radioactivity, as shown in Table 2.

The aim of this work is to investigate the specific activity of imported zirconium samples, samples of ceramic tiles and sludges resulting from ceramic tile production. The result have been examined in 
the light of the existing Iranian limit for the combined concentrations of ${ }^{238} \mathrm{U},{ }^{232} \mathrm{Th}$ and ${ }^{40} \mathrm{~K}$ which are $1800 \mathrm{~Bq} \mathrm{~kg}^{-1}, 900 \mathrm{~Bq} \mathrm{~kg}^{-1}$ and $11000 \mathrm{~Bq} \mathrm{~kg}^{-1}$, respectively [5].

Table 1. Radioactivity in the earth's crust, ores and mineral sands.

\begin{tabular}{|c|c|c|c|}
\hline \multirow[b]{2}{*}{ Material } & \multicolumn{2}{|c|}{ Activity $\left(\mathrm{Bq} \mathrm{kg}^{-1}\right)$} & \\
\hline & ${ }^{238} \mathrm{U}$ & ${ }^{232} \mathrm{Th}$ & \\
\hline Earth's crust & 33 & 34 & NCRP (1988) [9] \\
\hline Bauxite ore & 250 & 200 & UNSCEAR (1988) [10] \\
\hline Copper ore & $30-80$ & $23-110$ & UNSCEAR (1988) \\
\hline Phosphate rock & $1300-2300$ & & UNSCEAR (1982) [11] \\
\hline Zircon sand & $>500$ & $>500$ & UNSCEAR (1988) \\
\hline
\end{tabular}

Table 2. Radioactivity threshold levels for natural radionuclides. Euratom, 1996 [12].

\begin{tabular}{lcc}
\hline Radionuclide & Activity $(\mathrm{Bq})$ & Concentration $\left(\mathrm{Bq} \mathrm{kg}^{-1}\right)$ \\
\hline${ }^{40} \mathrm{~K}$ & $10^{6}$ & $10^{5}$ \\
${ }^{238} \mathrm{U}$ & $10^{3}$ & $10^{3}$ \\
${ }^{235} \mathrm{U}$ & $10^{4}$ & $10^{4}$ \\
${ }^{232} \mathrm{Th}$ & $10^{3}$ & $10^{3}$ \\
\hline
\end{tabular}

\section{MATERIALS AND METHODS}

The samples selected for this work are; zirconium minerals, final products (wall and floor tiles) and sludges resulting from the production cycle. The zirconium minerals are used in the ceramic industry for production of ceramic colors, glazes, tiles and sanitary and table ware. Concerning the final products, the samples chosen are representative of the main types of ceramic tiles produced in Iran. Ceramic sludges are the solid wastes produced by the waste water treatment plant of the ceramic factory.

All samples have been powdered to average particle size of approximately $1 \mathrm{~mm}$ and dried for $2 \mathrm{~h}$ at $105{ }^{\circ} \mathrm{C}$, accurately weighed, then placed in $300 \mathrm{~g}$ plastic container and sealed. Measurements have been carried out on sealed samples, after 'aging time' of about 21 days, in order to allow the re-establishment of radioactive equilibrium between ${ }^{222} \mathrm{Rn}$ and its short-lived daughter products.

The measurements of natural radioactivity level performed by gamma spectrometry, using a high purity germanium (HPGe) detector connected to a MCA. The resolution of this type detector is particularly useful for activity measurements of the uranium and thorium chain members which present peaks very close to each other.

The energy resolution (full-width at half maximum of the system is $1.9 \mathrm{keV}$ at $1332 \mathrm{keV}$ for ${ }^{60} \mathrm{Co}$ with $40 \%$ relative efficiency. The detector is placed in a well consisting of layer of $10 \mathrm{~cm}$ thick of lead with cadmium-copper coating in the inner side. The system is equipped with software (CANBERRA SPECTR-AT V4.3) for data acquisition and analyzing. The counting time was between $10^{4}$ and $6 \times 10^{4}$ seconds (2.8-16.7 h) depending on the specific activity of the samples. The calibration sources used are (RGU-1, RGTh-1 and RGK-1) for uranium, thorium and potassium from International Atomic Energy Agency. The background was measured for $6 \times 10^{4}$ seconds and subtracted from the sample spectra.

Assuming secular equilibrium in the uranium and thorium decay series, the ${ }^{238} \mathrm{U}$ and the ${ }^{232} \mathrm{Th}$ activities were determined indirectly via activities of their daughter products [6].

The nuclides chosen are ${ }^{214} \mathrm{Bi}(609 \mathrm{keV}),{ }^{214} \mathrm{~Pb}(352 \mathrm{keV}),{ }^{208} \mathrm{Tl}(583 \mathrm{keV})$ and ${ }^{228} \mathrm{Ac}(911 \mathrm{keV})$ for ${ }^{238} \mathrm{U}$ and ${ }^{232} \mathrm{Th}$, respectively. The specific activity of ${ }^{40} \mathrm{~K}$ was determined directly by $1461 \mathrm{keV}$ photopeak. 


\section{RESULTS AND DISCUSSION}

The specific activities of uranium, thorium and potassium measured in the samples are present in Table 3 (Zirconium minerals) and Table 4 (tiles and sludges). The ${ }^{238} \mathrm{U}$ concentration, ranging from 3000 to $10000 \mathrm{~Bq} \mathrm{~kg}^{-1}$, is higher than concentration of ${ }^{232} \mathrm{Th}\left(500-1800 \mathrm{~Bq} \mathrm{~kg}^{-1}\right)$ and ${ }^{40} \mathrm{~K}(50-800)$ in all samples.

The measured specific activities in the mineral show that the specific activity of baddeleyite is higher than that of zirconium silicate and agree with other recent works [7, 8].

The result of ceramic tiles shows that tiles usually contain small amounts of zirconium compound and therefore are not a cause of concern from the radiation protection point of view; in fact they produce negligible additional dose values.

The ${ }^{238} \mathrm{U}$ concentration in sludges is higher that than in the end product (tiles). The ceramic sludges can contain appreciable concentrations of zirconium compound and slightly higher than those in earth's crust.

Table 3. Specific activities of zirconium mineral samples.

\begin{tabular}{|c|c|c|c|c|c|c|}
\hline & Mineral & $\begin{array}{l}\text { imported } \\
(1999-2001)\end{array}$ & $\begin{array}{l}\text { weight } \\
\text { (tons) }\end{array}$ & ${ }^{238} \mathrm{U}$ & $\begin{array}{c}{ }^{232} \mathrm{Th} \\
\left(\mathrm{Bq} \mathrm{kg}^{-1}\right)\end{array}$ & ${ }^{40} \mathrm{~K}$ \\
\hline \multirow[t]{2}{*}{1} & zircon & South Africa & 60 & 4400 & 610 & 60 \\
\hline & & & & \pm 210 & \pm 35 & \pm 8 \\
\hline \multirow[t]{2}{*}{2} & - & Italy & 310 & 3500 & 550 & 55 \\
\hline & & & & \pm 170 & \pm 34 & \pm 7 \\
\hline \multirow[t]{2}{*}{3} & - & Ukraine & 20 & 2100 & 460 & 50 \\
\hline & & & & \pm 120 & \pm 40 & \pm 7 \\
\hline \multirow[t]{2}{*}{4} & - & Germany & 20 & 2700 & 590 & 65 \\
\hline & & & & \pm 140 & \pm 37 & \pm 8 \\
\hline \multirow[t]{2}{*}{5} & - & Belgium & 10 & 3100 & 570 & 77 \\
\hline & & & & \pm 150 & \pm 35 & \pm 9 \\
\hline \multirow[t]{2}{*}{6} & baddeleyite & South Africa & 40 & 11500 & 1800 & 310 \\
\hline & & & & \pm 450 & \pm 60 & \pm 20 \\
\hline \multirow[t]{2}{*}{7} & & Ukraine & 160 & 4300 & 425 & 65 \\
\hline & & & & \pm 180 & \pm 37 & \pm 8 \\
\hline 8 & & Germany & 60 & 2240 & 470 & 74 \\
\hline
\end{tabular}

Table 4. Specific activities of ceramic tile samples and sludge.

\begin{tabular}{lccc}
\hline Material & ${ }^{238} \mathrm{U}$ & ${ }^{232} \mathrm{Th}$ \\
$\left(\mathrm{Bq} \mathrm{kg}^{-1}\right)$ & ${ }^{40} \mathrm{~K}$ \\
\hline Glazed tile & $62 \pm 8$ & $54 \pm 7$ & $810 \pm 38$ \\
Stoneware & $58 \pm 6$ & $60 \pm 6$ & $570 \pm 35$ \\
sludge & $150 \pm 17$ & $59 \pm 6$ & $317 \pm 22$ \\
\hline
\end{tabular}

\section{CONCLUSION}

The following considerations from the point of view of radiation protection should taken into account;

- South Africa minerals are more radioactive than other imported countries

- Italy is the major zircon supplier (1999-2001) for the Iranian ceramic industry

- In the ceramic industry zircon widely used as an opacifier 
The high activities in sample 1 and 6 can be explained by the origin of the mineral itself (both imported from South Africa). In fact it is known that zirconium minerals coming from South Africa have specific activities generally higher than other countries. The comparison between the specific activities of the earth's crust and the investigated zircon sands shows the specific activities of ${ }^{238} \mathrm{U}$ are up to two orders of magnitude. The high level of radioactivity can be explained that uranium and thorium atoms are easily incorporated in crystalline structure of the zirconium; furthermore, zircon ores undergo an enrichment during sand processing which produce almost pure zirconium silicate [6].

Therefore zircon minerals used in the ceramic industry, are usually included in the category of sources of technology enhanced natural radioactivity.

On the basis of the Iranian threshold limit for the natural concentrations in imported minerals, it appears that more specific regulation on zirconium compound used in ceramic industry are necessary.

\section{References}

[1] Beretka, J. and Mathew, P.J., "Natural radioactivity of Australian building material industrial washes and by-products", Health Physics 48 (1985) 87-95.

[2] Boothe, G.F., Stewart Smith, D., Wagstaff, D. \& Dibblee, M., "The radiological aspects of zircon sands use", Health Physics 38 (1980) 393-398.

[3] Ganbogi, J.M. Zirconium and hafnium U.S., Geological Survey. Minerals information Reston, Virginia, U.S.A (1997).

[4] Basic Radiation Safety Standards, National Radiation Protection Department, Tehran, Iran (1999).

[5] Ghiassi-Nejad, M., Beitollahi, M.M., Fallahian, N., Amidi and J. Ramezani, H. "Concentrations of natural radionuclides in imported minerals substances". Environmental International 26 (2001) 557-560.

[6] Bruzzi, L, Baroni, M., Mazzotti, G., Mele, R. and Righi, S., "Radioactivity in raw materials and end products in the Italian ceramic Industry". Journal of Environmental Radioactivity 47 (2000) $171-181$.

[7] Timmermans, G.W.M. and S.J. Vander, "Environmental and occupational impacts of natural radioactivity from some non-nuclear industries in the Netherlands". Journal of Environmental Radioactivity 23 (1996) 97-104.

[8] Johnston, G.F., "An evaluation of radiation and dust hazard at mineral sand processing plan". Health Physics 60 (1991) 781-787.

[9] NCRP., "Measurement of radon and radon daughters in air". NCRP Report 97 Bethesda, Maryland, USA (1998).

[10] UNSCEAR., "Sources, effects and risks of ionizing radiation". Report to the General Assembly. Annex A, United Nations, New York, USA (1988).

[11] UNSCEAR., "Sources, effects and risks of ionizing radiation". Report to the General Assembly. Annex A, United Nations, New York, USA (1982).

[12] EC Directive 96/29/Euratom (13/05/1996). Gazzetta Ufficiale della Comunita Europea 29/06/1996, no. L159. 